Trinity College

Trinity College Digital Repository

Faculty Scholarship

3-2014

Is Capitalist Globalization Inevitable in the Marxian Paradigm?

Miguel D. Ramirez

Trinity College, miguel.ramirez@trincoll.edu

Follow this and additional works at: https://digitalrepository.trincoll.edu/facpub

Part of the Economics Commons 


\section{Journal of the History of Economic Thought}

http://journals.cambridge.org/HET

Additional services for Journal of the History of Economic

Thought:

Email alerts: Click here

Subscriptions: Click here

Commercial reprints: $\underline{\text { Click here }}$

Terms of use : Click here

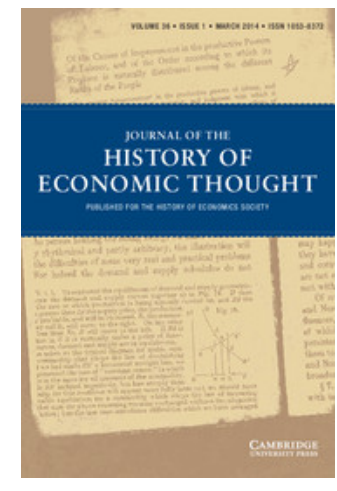

\section{Is Capitalist Globalization Inevitable in the Marxian Paradigm?}

Miguel D. Ramírez

Journal of the History of Economic Thought / Volume 36 / Issue 01 / March 2014, pp 83 - 95

DOI: 10.1017/S1053837214000042, Published online: 04 March 2014

Link to this article: http://journals.cambridge.org/abstract S1053837214000042

How to cite this article:

Miguel D. Ramírez (2014). Is Capitalist Globalization Inevitable in the Marxian Paradigm? . Journal of the History of Economic Thought, 36, pp 83-95 doi:10.1017/S1053837214000042

Request Permissions : $\underline{\text { Click here }}$ 


\title{
IS CAPITALIST GLOBALIZATION INEVITABLE IN THE MARXIAN PARADIGM?
}

\author{
BY \\ MIGUEL D. RAMÍREZ
}

\begin{abstract}
This paper examines Marx's views on capitalist globalization and its supposed inevitability, and contends that they underwent a substantial evolution and revision after the publication of the Communist Manifesto. In the case of China, a prime example of the Asiatic mode of production, Marx even doubted whether globalization (capitalism) would ever be able to accomplish its historical mission of developing the forces of production and creating the material conditions for a higher mode of production, viz., communism. In the Russian case, he seriously entertained the notion that it could bypass the hardships and vicissitudes of capitalism and forge its own unique path to socialism. If accepted, this interpretation represents a serious challenge to the universality and validity of Marx's materialist conception of history.
\end{abstract}

\section{INTRODUCTION}

In recent years, a number of Marxian scholars have argued that the rapid integration of goods and financial markets (globalization) that the world economy has experienced since the demise of the Soviet Union and its satellites is vindication of Marx's and Engels' prescient analysis in the Communist Manifesto (CM), Capital, and in their works addressing colonial matters, written more than 150 years ago (see Clarke 2000; Dupuy 1998; Foster 2000; Jellison and Gottheil 2009; Moseley 1997 and 2009; and Sutcliffe 2002). Moreover, the main underlying economic reason given for the geographical expansion of capitalism (away from western Europe and England in particular) into a global system has been attributed, primarily, to Marx's much maligned "law of the tendency of the rate of profit to fall" (see Jellison and Gottheil 2009, and Mosely 1997 and 2009).

Trinity College, Hartford, CT. The author wishes to express his thanks to the editors of this journal and to two anonymous reviewers for their valuable comments and suggestions for improvement. 
This paper does not necessarily take issue with the contention that the (early) Marx and Engels believed that the ultimate victory of socialism was predicated on the universalization (and necessity) of capitalism, ${ }^{1}$ but contends that the more mature (and late) Marx had significantly revised his views on both the inevitability of capitalist globalization in the non-European world and whether capitalism, independent of its inevitability, was ultimately necessary for the victory of socialism. That is, Marx came to the conclusion that historical development, particularly in the Asian and Russian cases, was much more multilineal than he had thought (based on his earlier analysis of how capitalism had developed in western Europe and England). ${ }^{2}$ Thus, any interpretation that ignores this important development in Marx's thinking is both incomplete and misleading when applied to the historical reality of non-European societies.

It is argued below that Marx's views on the process of capitalist globalization (imperialism in former times) in the non-European world, particularly the so-called Asiatic mode of production, exhibited, over time, a marked evolution and nuance, some would even say inconsistency, with his materialist conception of history. In support of this view, not only are Marx's trenchant editorial dispatches for the New York Tribune during the 1850s presented as textual evidence, but also, for the first time in a systematic manner, so are his more mature and serious writings in Capital, the Grundrisse, and Theories of Surplus Value (TSV), Part III. These writings clearly suggest that capitalist globalization in the non-European world, particularly China, would be a highly uneven, difficult, and protracted process. Finally, this essay presents and discusses Marx's important and controversial writings, a few years before his death, relating to whether Tsarist Russia could establish a socialist society while bypassing, altogether, internal capitalist development; i.e., the late Marx came to seriously doubt whether prior universalization of capitalism is a necessary condition for the ultimate victory of socialism. ${ }^{3}$

\footnotetext{
${ }^{1}$ Marx (1848) declares in "On the Question of Free Trade" that he is against the "protective system" of his day because it is "conservative," and he is reluctantly in favor of the free trade system, which he equates with the complete 'freedom of capital' to move across national boundaries, because it "is destructive [progressive]. It breaks up old nationalities and pushes the antagonism of the proletariat and the bourgeoisie to the extreme point.... All the destructive phenomena which unlimited competition gives rise to within a country are reproduced in more gigantic proportions on the world market. In a word, the free trade system hastens social revolution" (p. 450). By "social revolution," Marx clearly meant a Communist revolution because, as he states in the $C M$, "All the preceding classes ... sought to fortify their already acquired status by subjecting society to their conditions of appropriation. The proletarians cannot become masters of the productive forces of society, except by abolishing their own previous mode of appropriation, and thereby also every [my emphasis] other previous mode of appropriation.... What the bourgeoisie ... produces, above all, is its own grave-diggers. Its fall and the victory of the proletariat are equally inevitable" (pp. 76, 79). See also Marx's statements in the $C M$, pp. 63-65, his 1852 essay in the New York Daily Tribune entitled "Free Trade and the Chartists" (1852, p. 333), and Theories of Surplus Value, Part III ([1862-63] 1968), p. 253.

${ }^{2}$ This essay does not address or question Marx's tenacious linearity in terms of the end point of history. That is to say, if historical evolution is indeed multilineal and the outcome of historically specific and contingent class struggles, why should all such development, including those that do not lead to capitalism à la western Europe, culminate in communism?

${ }^{3}$ That is, it is possible to reject the inevitability of capitalist globalization, as the mature Marx apparently did in the Chinese case, but still believe that the ultimate victory of capitalism is predicated on the prior universalization of capitalism.
} 
The paper is organized as follows. The first section discusses Marx's extensive writings on the impact of capitalist globalization (imperialism) in the colonies, particularly India and China. The second focuses on Marx's controversial writings on whether Tsarist Russia could forge its own unique path to socialism. While these writings highlight continuity with other earlier and later works, such as the Communist Manifesto $(C M)$ and Capital, they also reveal a significant evolution in his views, even to the point of reversal or contradiction on major tenets relating to his materialist conception of history.

\section{MARX, GLOBALIZATION, AND THE SO-CALLED ASIATIC MODE OF PRODUCTION}

Marx showed that accumulation is theoretically possible in a highly abstract and closed capitalist system, but, as attested by his incisive analysis in Capital, Vol. I, Part VIII ("Primitive Accumulation") and Capital, Vol. III, he was well aware that it is a far cry from the way historical capitalism actually appeared and expanded in a non-capitalist world. Marx believed that capitalism, continually threatened by a lack of effective demand as a result of the exploitation of workers and the capitalists' drive to accumulate, needed to (and historically did) find enough outlets for its products, via the conquering of new markets, in order to realize the ever-increasing surplus-value contained within them. He also believed initially, as indicated by his writings in the $C M$, that the process of capitalist globalization would inevitably overcome any economic and geopolitical barriers to its further expansion and create "a world in its own image." That is, the (early) Marx believed that the falling rate of profit and/or underconsumptionist tendencies in the advanced capitalist nations inexorably push toward globalization because the preconditions for capitalism existed in other countries, and if not, they could be readily created by applying sufficient political pressure or lethal force.

However, in his later, more mature writings (on Asia and Russia, to be discussed below), Marx appears to have significantly revised his earlier views on capitalist globalization. Far from being inevitable, he now believed it would be a highly protracted process that, under certain conditions, particularly in the case of China, might never take place, owing to the nature and resilience of the Asiatic mode of production. In other words, the origins and rapid development of capitalism in western Europe, on the one hand, and its slow and uncertain emergence in Asia, on the other hand, are the result of inherent differences in the preceding social and economic structures of these regions of the world (see Brewer 1990). If this interpretation is accepted, the implications are considerable and far-reaching, because it not only challenges the universality and validity of Marx's materialist conception of history, but, by conceding that there may be a limit to the geographic expansion of historical (actually existing) capitalism, it disrupts and threatens the process of accumulation by preventing capitalists' full access to new markets, cheap raw materials, and fresh supplies of labor power. That is, if the economic preconditions for capitalism do not exist or cannot be readily created in other regions of the world, then capitalist globalization, whether driven by a falling rate of profit or strong underconsumptionist tendencies, is, at best, a highly localized, protracted, and uneven process or, at worst, doomed to failure. 


\section{The Asiatic Mode of Production: India and China}

There is no question that Marx and Engels viewed the annexation of India by the British Raj or the British opium trade in China as necessary developments in world history in terms of developing the productive forces of society, but not as cause for celebration, given the inherent inhumanity of the imperialist mission and the self-serving cruelty and hypocritical behavior of the "civilization mongers," as Marx often referred to the British colonizers. In fact, nowhere is this sentiment more evident than in the very article where Marx analyzes the "progressive impact" of British colonial rule in India. Towards the end of the article, entitled "The Future Results of British Rule in India," where he had earlier observed that "The railway system will therefore become, in India, truly the forerunner of modern industry," he also informs the reader that he "cannot part with the subject of India" without making some concluding remarks, which, given their telling nature, are worth quoting in full.

The profound hypocrisy and inherent barbarism of bourgeois civilization lies unveiled before our eyes, turning from its home, where it assumes respectable forms, to the colonies, where it goes naked. They are the defenders of property, but did any revolutionary party ever originate agrarian revolutions like those in Bengal, in Madras, and in Bombay? Did they not, in India, to borrow an expression of that great robber, Lord Clive himself, resort to atrocious extortion, when simple corruption could not keep pace with their rapacity? While they prated in Europe about the inviolable sanctity of the national debt, did they not confiscate in India the dividends of the rajahs, who had invested their private savings in the Company's own funds? While they combated the French revolution under the pretext of defending "our holy religion," did they not forbid, at the same time, Christianity to be propagated in India, and did they not, in order to make money out of the pilgrims streaming to the temples of Orissa and Bengal, take up the trade in the murder and prostitution perpetrated in the temple of Juggernaut? These are the men of 'Property, Order, Family, and Religion.' ([August 8, 1853] 2007a, p. 224)

Marx viewed the wholesale and forcible destruction of "primitive" societies, such as those of India and China, as necessary and progressive because he believed that the Asian mode of production did not have "a history" in the sense that western European civilization did. ${ }^{4} \mathrm{He}$ believed that Asian societies lacked internal dialectal forces_-classes and class conflict - capable of generating progressive historical change (development of the productive forces and the creation of new property relations of production)

\footnotetext{
${ }^{4}$ Paul Baran (1968) would strongly disagree with Marx's generalization because his own extensive studies of the Indian economy (and Japan) led him to conclude that India had attained significant industrial development prior to its conquest by the British Raj, and that, after its forcible colonization, the country's further economic development was undermined and distorted as a direct result of the massive extraction and transfer of her wealth (which Baran estimates at no less than $10 \%$ of India's gross national income) to the imperial power, thereby depriving her of much-needed resources for investment and future growth (see pp. 144 150). Baran also contrasts the tragic case of India with that of Japan, which escaped colonization under the Meiji Restoration (1868-1912) and became a major industrial and military power (ibid., pp. 151-163); Tsarist Russia would find this out the hard way when its expansionist policy in the Far East came to a swift and humiliating end at the hands of the Japanese during the Russo-Japanese War (1904-05). For further details, see Baran (1968) and Brewer (1990, ch. 7).
} 
in the manner that feudalism's decay created propitious economic conditions for the growth of the bourgeois mode of production in western Europe. For example, insofar as India is concerned, he writes:

India then could not escape the fate of being conquered, and the whole of her past history, if it be anything, is the history of the successive conquests she has undergone. Indian society has no history at all, at least no known history. What we call its history is but the history of the successive invaders who founded their empires on the passive basis of that unresisting and unchanging society. The question, therefore, is not whether the English had the right to conquer India, but whether we are to prefer India conquered by the Turk, by the Persian, by the Russian, to India conquered by the Briton. (2007a, pp. 219-220)

Marx held a similar (stereotypical) view with respect to China in an article published in the German newspaper Die Presse (July 7, 1862), entitled "Chinese Affairs," in which he discussed the nature of the Taiping Rebellion (1850-64) against Manchu colonial rule.

Some time before the tables began to dance, China—-this living fossil—started revolutionizing. By itself there was nothing extraordinary in this phenomenon, since the Oriental empires always show an unchanging social infrastructure coupled with unceasing change in the persons and tribes who manage to ascribe to themselves the political superstructure.

In this connection, Jellison and Gottheil are correct to argue that the (early) Marx "was among the first-if not the first - of the modern social scientists to recognize the inevitability [and necessity] of globalization" (2009, p. 36). In their view, Marx regarded the conquering and subjugation of India (and China) as necessary because "'Capitalism and the Globalization' process ... will create out of an economically diverse set of nations a 'unified whole,' more humane than any of its parts had ever been" (ibid.). Clearly, this is echoed by Marx's own words in the $C M$ where he declares in no uncertain terms that

The Bourgeoisie, by the rapid improvement of all instruments of production, by the immensely facilitated means of communication, draws all, even the most backward, nations into civilization.... it compels all nations, on pain of extinction, to adopt the bourgeois mode of production; it compels them to introduce what it calls civilization into their midst, i.e., to become bourgeois. In one word, it creates a world in its own image. (p. 64; see also his remarks above "On the Question of Free Trade," op. cit)

Further, Marx believed that once capitalism takes hold of a society, it "ruthlessly forces the human race to produce for production's sake; [it] ... forces the development of the productive powers of society, and creates the material conditions, which alone can form the real basis of a higher form of society, a society in which the full and free development of every individual forms the ruling principle" (1967, Vol.I, p. 592).

It is evident that the Marx of the $C M$ viewed capitalist globalization as both inevitable and necessary (even desirable) for the ultimate attainment of human freedom or communism. However, Marx's more mature writings on Asia, particularly China, suggest that capitalist globalization is not preordained and would be a highly uneven and drawn-out process that might never take place. 
In Marx's mind, the Asiatic mode of production stood uneasily (and inconsistently) apart, both geographically and conceptually, from the other Western-based modes of production that formed integral parts of his materialist conception of history; viz., "the ancient, the feudal, and the modern bourgeois methods [modes] of production" he so aptly describes in the preface to A Contribution to the Critique of Political Economy (1859) (see Avineri [1969] 1976). The Asiatic mode, as opposed to the feudal or bourgeois, did not possess an endogenous mechanism of change via class formation and conflict that would destroy the existing (property) relations of production of one mode of production, say feudalism, and replace them with new and better suited ones to the advancing technology, thus paving the way for the further development of society's forces of production; in other words, the Asiatic mode was incapable of generating capitalism from within. ${ }^{5}$

Based on Marx's extensive study of India's (and China's) political and military history as well as its land tenure system, he concluded that Asiatic society's "lack of history" and stubborn resistance to change via the penetration of trade alone were the result of three important factors. ${ }^{6}$ First, the vast bottom of these societies consisted of a multitude of small and isolated villages that were virtually self-sufficient owing to the "self-sustaining union" of primitive agriculture and handicraft industries within each village (see 1967, Vol. I, p. 358; and Grundrisse, Notebook V, pp. 486 and 493). Second, these communities (more so in the case of India than China) were characterized by the absence of private ownership in land, although Marx noted that "there is both private and common possession and use of land" (1967, Vol. III, pp. 791-792; and Grundrisse, Notebook V, p. 484). Third, there existed no autonomous feudal class (in the western European sense) or, for that matter, any intermediate classes of any significance, but an authoritarian state or despotic regime at the apex whose main productive function, for climatic and geographic reasons, was to build and maintain large-scale irrigation works and roads (financed and undertaken, respectively, via the taxation of the surplus product and surplus labor of the villages) (see 1967, Vol. I, pp. 357-358; Grundrisse, Notebook IV, pp. 473-474; and Brewer 1990, pp. 53-57). This special and unique set of historical, institutional, and geographic factors led Marx to conclude that the resilience of the Asiatic mode of production might be strong enough to prevent globalization (imperialism) from accomplishing its historical mission, as the following passage from his article "Trade with China" (2007d) attests:

It is this same combination of husbandry with manufacturing industry, which, for a long time, withstood, and still checks, the export of British wares to East India; but there that combination was based upon a peculiar combination of the landed property which the British, in their position as the supreme landlords of the country, had it in

\footnotetext{
${ }^{5}$ It is admittedly puzzling that, except for a few insightful remarks regarding the similarity between Japan's feudal organization of landed property and that of western Europe during the Middle Ages in a footnote in Capital, Vol. I, p. 718, Marx had next to nothing to say about Japan's successful defensive modernization, which began under the (late) Tokugawa dynasty (1853-1867) and was intensified under the Meiji Restoration (1868-1912). Just a casual acquaintance with Japanese economic history during this period would have directly challenged (and refuted) Marx's views regarding the stagnant and unchanging nature of the Asiatic mode of production. For further details, see Avineri ([1969] 1976, pp. 254-550) and Baran (1968, ch. V).

${ }^{6}$ Both Brewer (1990) and Avineri ([1969] 1976) are of the opinion that, among his contemporaries, Marx's knowledge of Indian (and Chinese) society was unsurpassed when it came to historical and institutional detail, and also in terms of outlining the long-run impact of European imperialism on the socio-economic structure of these colonies. See also Howard and King (1985).
} 
their power to undermine, and thus forcibly convert part of the Hindoo self-sustaining communities into mere farms, producing opium, cotton, indigo, hemp, and other raw materials, in exchange for British stuffs. In China, the English have not yet wielded this power, nor are they likely ever to do so. (p. 47, my emphasis)

Marx's careful and detailed studies of British trade with China also led him to formulate the following explanation for the British capitalists' inability to penetrate the Chinese cloth market via trade alone: the underlying reason that British (and American) manufacturers could not penetrate and undersell "cloth woven by hand in the most primitive looms" stemmed from the unique ability of these self-sufficient Chinese villages to combine and coordinate their family labor, old and young, during the agricultural off-season, not only to card and spin the cotton into yarn, but also to weave it into homespun stuff (cloth) with which "nine out of every ten beings in this country are clothed" (ibid., p. 45). ${ }^{7}$ Moreover, the village's possession (not ownership) of land and the instruments of production, both privately and in common, including a loom in "every well-conditioned homestead," enabled them to avoid being undercut by "the most advanced factory system of the world" (ibid.). ${ }^{8}$ In other words, Marx attributed the resilience of these Chinese villages to the fact that the direct producers controlled their own means of production (including common possession of land) and, equally as important, they were able to effectively pool and coordinate the village's agricultural labor when it was slack (during the off-season) with handicraft (cloth) production. Furthermore, Marx believed that because capitalist penetration, in its competitive phase, could not be achieved by economic means (trade) alone in China-or, for that matter, India - it was necessary for the British government to resort to direct political pressure and lethal force (via the Opium Wars) to pry open the "Celestial Empire."

It might be objected that these journalistic pieces, pregnant with institutional insight and historical detail as they are, do not form part of Marx's more comprehensive and mature works, such as those found in Capital, the Grundrisse, and TSV,

\footnotetext{
${ }^{7}$ Marx makes a similar assessment regarding the limited size of the Chinese market in his article entitled "The Anglo-Chinese Treaty" ([1858] 2007c), where he states that "It appears ... that, generally speaking, the consuming powers of the Celestials have been greatly overestimated. With the present economical framework of Chinese society, which turns upon diminutive agriculture and domestic manufactures as its pivots, any large import of foreign [British] produce is out of the question" (p. 36). See also his article entitled "The British and Chinese Treaty" ([1858] 2007e).

${ }^{8}$ There is no escaping the stark contrast between Marx's remarks above and those he made ten years earlier in the $C M$, in which he declared in no uncertain terms that "The bourgeoisie, by the rapid transformation of all instruments of production, by the immensely facilitated means of communication, draws all, even the most backward, nations into civilization. The cheap price of its commodities are the heavy artillery with which it batters down all Chinese walls, with which it forces the underdeveloped nations' obstinate hatred of foreigners to capitulate" (1964, p. 64).

${ }^{9}$ See Marx's incisive article on the "Arrow incident," the catalyst for the Second Opium War (1856-1860), entitled "The Anglo-Chinese Conflict," published on January 23, 1857 (2007c). Marx documents the hypocrisy and naked self-interest of British officials and diplomats, and argues that the forcible boarding of a Chinese vessel falsely accused of smuggling opium was nothing but a pretext by the British government to attack China, as the following passage attests: "It is, perhaps, a question whether the civilized nations of the world will approve this mode of invading a peaceful country, without previous declaration of war, for an alleged infringement of the fanciful code of diplomatic etiquette. If the first Chinese [Opium] war, in spite of its infamous pretext, was patiently looked upon by the other powers, because it held the prospect of opening trade with China, is not the second war likely to obstruct that trade for an indefinite period?" (p. 17).
} 
Part III, ${ }^{10}$ but, as the following passage from Capital, Vol. III (and the other cited works) attests, there is considerable continuity, if not always consistency, in Marx's views on the nature of the Asiatic mode of production and the ability (or, better still, inability) of British capitalism to penetrate and subjugate it.

The obstacles presented by the internal solidity and organization of pre-capitalist, national modes of production to the corrosive influence of commerce are strikingly illustrated in the intercourse of the English with India and China. The broad basis of the mode of production here is formed by the unity of small-scale agriculture and home industry, to which in India we should add the form of village communities built upon the common ownership [possession] of land, which ... was the original form in China as well. In India the English lost no time in exercising their direct political and economic power ... English commerce exerted a revolutionary influence on these communities and tore them apart only in so far as the low prices of its goods served to destroy spinning and weaving industries.... And even so this work of dissolution proceeds very gradually. And still more slowly in China, where it is not reinforced by direct political power. The substantial economy and saving in time afforded by the association of agriculture with manufacture put up a stubborn resistance to the products of the big industries, whose prices include the faux frais of the circulation process which pervaded them. (pp. 333-334, my emphasis)

Of course, if one accepts Marx's reluctant conclusion that these self-sufficient, hereditary, village communities are not going to disappear anytime soon (if ever), as he hoped they would, then, as Avineri (1976) correctly observes, "Marx's concept of the Asiatic mode of production thus poses a serious challenge to the assumption that Marx developed a philosophy of history universal in its applicability" (p. 234). ${ }^{11}$

\footnotetext{
${ }^{10}$ In Notebook V, "The Chapter on Capital," of the Grundrisse, Marx makes essentially the same point. He declares that "The Asiatic form necessarily hangs on most tenaciously and for the longest time. This is due to the presupposition that the individual does not become independent vis-à-vis the commune; that there is a self-sustaining cycle of production, unity of agriculture and manufactures, etc. If the individual changes his relation to the commune, he thereby changes and acts destructively upon the commune; as on its economic presupposition" ([1857-58] 1973, p. 486; for similar remarks, see [1867] 1967, Vol. I, pp. 357-358; and Grundrisse, Notebook IV, pp. 472-475). Finally, Marx, in TSV, Part III, discusses in several instances the essential difference between the European feudal mode of production and the Asiatic mode in terms of ownership of land, mobility of labor (and capital), intensity and duration of work, and the "revolutionary" role played by usury in the disintegration of the feudal mode of production, but not in the Asiatic case; for example, he notes that "Usury can continue to exist for a long time in Asiatic forms of society without bringing about real disintegration, but merely giving rise to economic decay and political corruption", (p. 531; see also pp. 416-417, 420, 422-423, 434-435, and 444; and [1867] 1967, Vol. III, pp. 597-598). ${ }^{11}$ It should be noted that Avineri's seminal essay relies almost exclusively on Marx's dispatches from the New York Tribune, and it is not evident that he was even aware of the extensive nature (and continuity) of Marx's writings on the subject in Capital, the Grundrisse, and TSV, Part III. This essay attempts to fill this lacunae in the extant literature by establishing the continuity and evolution of Marx's thought on this highly important and controversial topic. In more ways than one, Marx's analysis of the Asiatic mode of production and its resilience in terms of blocking the advance of capitalism provides the basis for the pathbreaking works by P. P. Rey and C. Arrighi during the 1970s on the articulation (coexistence) of different modes of production (indigenous and capitalist) within a given (concrete) social formation in tropical Africa in the early twentieth century (Congo-Brazzaville and Rhodesia [Zimbabwe], respectively). Both authors extensively document that the relatively late penetration of capitalism into Africa was blocked or arrested for such a long time that the transition from one mode of production (tribal communal) to another (capitalist) became the "normal state of affairs" (for further details, see Brewer, op. cit., pp. 231-253).
} 


\section{The Semi-Asiatic Mode: Tsarist Russia}

In similar vein, Howard and King (1989) suggest that the late Marx, influenced by the Russian populists, no longer accepted the universality of capitalism (globalization) as a precondition for socialism, and took seriously the idea that, once capitalism had been established in western Europe and England, it was possible for Russia (a semi-Asiatic country, in his mind) to forge a unique, non-capitalist path to socialism led by the peasantry and intellectuals, rather than by the revolutionary proletariat. Howard and King's interpretation is corroborated not only by a series of highly interesting and remarkable letters Marx wrote on Russian social, political, and economic issues during the 1870 s, but also by what he wrote in a relatively unknown and highly important article entitled "On Social Relations in Russia" in 1874-75"12; followed by what Marx and Engels wrote in the preface to the Russian edition of the Communist Manifesto on January 21, 1882, a little over a year before Marx's death.

Turning to the letters, for example, in November 1877, Marx wrote a rejoinder to the editorial board of the Russian socialist journal Otechestvenniye Zapiski (Fatherland Notes), in which he declares that "In order that I might be specially qualified to estimate the economic development in Russia, I learned Russian, and then for many years studied the official publications and others bearing on this subject. I have arrived at this conclusion: If Russia continues to pursue the path she has followed since 1861 [abolition of serfdom], she will lose the finest chance ever offered by history to a people and undergo all the fatal vicissitudes of the capitalist regime" (p. 439). More startling, perhaps, is what Marx writes later in the same letter, where he suggests that the inevitability of capitalism, as proclaimed in the $C M$ and Capital, is confined to a "little corner" of the world; viz., western Europe, and is not applicable in a mechanical fashion to the non-European (Asiatic) world. He warns his readers not to

metamorphose my historical sketch of the genesis of capitalism in Western Europe into a historico-philosophic theory of the general path every people is fated to tread, whatever the historical circumstances in which it finds itself, in order that it may ultimately arrive at the form of economy which ensures, together with the greatest expansion of the productive powers of social labor, the most complete development of man. But I beg his pardon. (He is both honoring me and shaming me too much.) (p. 441)

Interestingly enough, Marx then goes on to describe similar developments (to the forcible separation of peasants from their land under feudalism) in different historical periods, such as the expropriation of the plebeians (free peasants) of ancient Rome, and concludes that it did not lead to the creation of proletarians and capitalists, but to a mode of production based on slavery. Thus, he concludes that "events strikingly analogous ... led to totally different results ... [and] one will never arrive there by using as one's master key a general historico-philosophical theory, the supreme virtue of which consists in being super-historical" (p. 441). Finally, Marx believed that Russia's "finest chance" of pursing a successful and unique non-capitalist development to

\footnotetext{
${ }^{12}$ Howard and King (op. cit.) seem to be completely unaware of the existence of this longer work because they characterize Marx's remarks on this highly important topic as brief (and conditional in nature), yet "they do show Marx as believing that capitalist development may not be the only path of historical progress, or the most beneficial" (p. 233).
} 
communism was predicated on a proletarian-led revolution in western Europe, given the relative backwardness of Russia's economy and its agrarian communes, the so-called obshchina. In the preface to the Russian edition of the Communist Manifesto, Marx and Engels write:

The Communist Manifesto had, as its object, the proclamation of the inevitable impending dissolution of modern bourgeois property. But in Russia we find, face-to-face with the rapidly flowering capitalist swindle and bourgeois property, just beginning to develop, more than half the land owned in common by the peasants. Now the question is: can the Russian obshchina though greatly undermined, yet a form of primeval common ownership of land, pass directly to the higher form of Communist common ownership? Or, on the contrary, must it first pass through the same process of dissolution such as constitutes the historical evolution of the West? The only answer to that possible today is this: If the Russian Revolution becomes the signal for a proletarian revolution in the West, so that both complement each other, the present Russian common ownership of land may serve as the starting point for a communist development. (1882)

Marx, anticipating Gerschenkron's (1965) (and L. Trostky's) ideas relating to the advantages of relative backwardness, seems to suggest that Russia, as a late lateindustrializer, could substitute for the "missing factors" by importing and using the more advanced Western industrial and agricultural technology, broadly defined, and "leap frog," under the right political and external conditions, into a higher mode of production without having to experience the trials and tribulations of generating capitalism from within. In relation to this point, there is no other interpretation a disinterested reader can infer from the remarkable letter Marx wrote in March 1881 to Vera Zasulich, where he emphatically states:

The historical situation of the Russian "rural commune" is unparalleled! Alone in Europe, it has kept going not merely as scattered debris such as the rare and curious miniatures in a state of the archaic type which one could still come across until quite recently in the West, but as the virtually predominant [my emphasis] form of popular life covering an immense empire. If it possesses in the communal ownership of the soil the basis of collective appropriation, its historical surroundings, its contemporaneity with capitalist production, lend it all the material conditions of communal labour on a vast scale. It is thus in a position to incorporate all the positive acquisitions devised by the capitalist system without passing through its Caudine Forks [i.e., undergo humiliation in defeat]. It can gradually replace parcel farming with large-scale agriculture assisted by machines, which the physical lie of the land in Russia invites. It can thus become the direct point of departure for the economic system towards which modern society tends, and turn over a new leaf without beginning by committing suicide.

The continuity and consistency in the (late) Marx's views on this highly important (and controversial) question are further evinced by his remarks in a slightly earlier (and relatively unknown) work entitled "On Social Relations in Russia," published between 1874 and 1875 . He writes:

It is clear that communal ownership in Russia is long past its period of florescence and, to all appearances, is moving towards its disintegration. Nevertheless, the possibility 
undeniably exists of raising this form of society to a higher one, if it should last until the circumstances are ripe for that, and if it shows itself capable of developing in such manner that the peasants no longer cultivate the land separately, but collectively; ... of raising it to this higher form without it being necessary for the Russian peasants to go through the intermediate stage of bourgeois small holdings. This, however, can only happen if, before the complete break-up of communal ownership, a proletarian revolution is successfully carried out in Western Europe, creating for the Russian peasant the preconditions requisite for such a transition, particularly the material things he needs, if only to carry through the revolution, necessarily connected therewith, of his whole agricultural system. (1874-75, p. 39; my emphasis)

It is readily apparent that the mature and late Marx — and, to a lesser degree, Engelshad significantly modified his earlier views in the Communist Manifesto on both the necessity (as a precondition for socialism) and the inevitability of capitalist globalization as it evolved in western Europe, and no longer believed, if he ever did, that a "onesize-fits-all" explanation was suitable for understanding the emergence of capitalism and its metamorphosis into a higher mode of production, particularly when it came to the Asiatic or semi-Asiatic modes of production prevalent in India, China, and Russia.

\section{CONCLUSION}

This paper has shown that Marx's views on capitalist globalization and its supposed inevitability underwent a substantial evolution and revision, even as early as five years after the publication of the Communist Manifesto. In his writings relating to India, and particularly to China and Russia, Marx is no longer certain that "the country that is more developed industrially only shows, to the less developed, the image of its own future" ([1867] 1967, Vol. I, p. 13). In the case of China, a prime example of the Asiatic mode of production, he even doubted whether capitalist globalization would ever be able to accomplish its historical mission of developing the forces of production and creating the material conditions for a higher mode of production; viz., communism. In the Russian case, a semi-Asiatic country in his mind, he seriously entertained the notion, towards the end of his life, that it could bypass the hardships and vicissitudes of capitalism and forge its own unique path to socialism, provided that it received help from a proletarian-led revolution in western Europe. That is, the ultimate victory of socialism, although conditional in nature, was no longer predicated on the prior universalization of capitalism. These are no small matters, for, if accepted, they represent a serious challenge to the universality and validity of Marx's materialist conception of history: the idea that each historical stage, say capitalism, grows dialectically out of the internal contradictions (tensions) of the previous stage, feudalism, and so on.

\section{REFERENCES}

Avineri, S. [1969] 1976. "Karl Marx on Colonialism and Modernization.” In M. C. Howard and J. E. King, eds., The Economics of Marx. New York: Penguin Books, pp. 235-257.

Baran, P. A. [1957] 1968. The Political Economy of Growth. New York: Monthly Review Press. 
Brewer, A. 1990. Marxist Theories of Imperialism: A Critical Survey. Second edition. New York: Routledge $\&$ Kegan Paul.

Clarke, S. 2001. "The Globalizaton of Capital, Crisis and Class Struggle.” Capital and Class 75 (Autumn): 93-102.

Dupuy, A. 1998. "Thoughts on Globalization, Marxism, and the Left," Latin American Perspectives 25 (6): 55-58.

Foster, J. 2000. “Marx and Internalization.” Monthly Review 52 (3): 11-22.

Gershenkron, A. 1965. Economic Backwardness in Historical Perspective. New York: Praeger Publishers.

Jellison, S. M., and F. M. Gottheil. 2009. "Marx and Engels: In Praise of Globalization.”Contributions to Political Economy 28: 35-46.

Howard, M. C., and J. E. King. 1985. The Political Economy of Marx. New York: Longman.

Howard, M. C., and J. E. King. 1989. A History of Marxian Economics: Volume I, 1883-1929. Princeton, NJ: Princeton University Press.

Lenin, V. I. [1917 1984. Imperialism, The Highest Stage of Capitalism. New York: International Publishers. Luxemburg, R. [1913] 1951. The Accumulation of Capital. London: Routledge \& Paul Kegan.

Mandel, E. [1962] 1971a. Marxist Economic Theory. Volume 1. New York: Monthly Review Press.

Mandel, E. [1968] 1971b. Marxist Economic Theory. Volume 2. New York: Monthly Review Press.

Marx, K.. [1848] 1964. The Communist Manifesto. New York: Simon \& Schuster.

Marx, K. 1848. "On the Question of Free Trade," In K. Marx and F. Engels: Collected Works. Volume 6. Moscow: Progress Publishers, various dates.

Marx, K. 1852. "Free Trade and the Chartists," In K. Marx and F. Engels: Collected Works. Volume 11. Moscow: Progress Publishers, various dates.

Marx, K. [1853] 2007a. "The Future Results of British Rule in India.” In James Ledbetter, ed., foreword by Francis Wheen, Dispatches for the New York Tribune: Selected Journalism of Karl Marx. New York: Penguin Books, pp. 219-225.

Marx, K. [1857] 2007b. “The Anglo-Chinese Conflict.” In James Ledbetter, ed., foreword by Francis Wheen, Dispatches for the New York Tribune: Selected Journalism of Karl Marx. New York: Penguin Books, pp. 11-16.

Marx, K. [1857-58] 1973. Grundrisse. New York: Vintage Books.

Marx, K. [1858] 2007c. “The Anglo-Chinese Treaty.” In James Ledbetter, ed., foreword by Francis Wheen, Dispatches for the New York Tribune: Selected Journalism of Karl Marx. New York: Penguin Books, pp. 31-35.

Marx, K. [1858] 2007d. "Trade with China." In James Ledbetter, ed., foreword by Francis Wheen, Dispatches for the New York Tribune: Selected Journalism of Karl Marx. New York: Penguin Books, pp. $42-50$.

Marx, K. [1858] 2007e. "The British and Chinese Treaty.” In James Ledbetter, ed., foreword by Francis Wheen, Dispatches for the New York Tribune: Selected Journalism of Karl Marx. New York: Penguin Books, pp. 36-41.

Marx, K. 1862. “Chinese Affairs.” In K. Marx and F. Engels: Collected Works. Volume 19. Moscow: Progress Publishers, various dates.

Marx, K. [1862-63] 1968. Theories of Surplus Value. Part III. New York: International Publishers.

Marx, K. [1867] 1967. Capital. Volumes I-III. New York: International Publishers.

Marx, K. 1874-75. “On Social Relations in Russia.” In K. Marx and F. Engels: Collected Works. Volume 24. Moscow: Progress Publishers, various dates.

Marx, K. [1877] 1959. "Fatherland Notes.” In L. S. Feuer, ed., Basic Writings on Politics and Philosophy. New York: Anchor Books.

Marx, K. 1881. First Draft of a Letter to Vera Zasulich. In K. Marx and F. Engels: Collected Works. Volume 24. Moscow: Progress Publishers, various dates.

Marx, K. 1882. Preface to the Manifesto of the Communist Party. Reproduced by Marxists.org, http:// www.marxists.org/archive/marx/works/1848/communist-manifesto/preface.htm\#preface-1882, accessed Jan. 7, 2013. 
Moseley, F. 1997. "The Rate of Profit and the Future of Capitalism.” Review of Radical Political Economics 29,4 (December 1): 23-41.

Moseley, F. 2009. "The U.S. Economic Crisis: Causes and Solutions.” Internationalist Socialist Review 64 (March-April): 1-14.

Sowell, T. 1967. "Marx’s Capital after One Hundred Years.” In M. C. Howard and J. E. King, eds., The Economics of Marx. New York: Penguin Books.

Sutcliffe, B. 2002. "How Many Capitalisms?” In M. Rupert and H. Smith, eds., Historical Materialism and Globalization. New York: Routledge, pp. 40-58. 